\title{
Should we tolerate climate denial?
}

\author{
Article
}

Accepted Version

McKinnon, C. (2016) Should we tolerate climate denial? Midwest Studies in Philosophy, 40 (1). pp. 205-216. ISSN 1475-4975 doi: https://doi.org/10.1111/misp.12056 Available at https://centaur.reading.ac.uk/65823/

It is advisable to refer to the publisher's version if you intend to cite from the work. See Guidance on citing.

To link to this article DOI: http://dx.doi.org/10.1111/misp.12056

Publisher: Wiley

All outputs in CentAUR are protected by Intellectual Property Rights law, including copyright law. Copyright and IPR is retained by the creators or other copyright holders. Terms and conditions for use of this material are defined in the End User Agreement.

\section{www.reading.ac.uk/centaur}

\section{CentAUR}

Central Archive at the University of Reading

Reading's research outputs online 


\section{$\underline{\text { Should We Tolerate Climate Change Denial? } 1}$}

\section{Forthcoming}

Midwest Studies in Philosophy (Vol XL, 2016): 'Ethics and Global Climate Change'

\section{Introduction: hope and danger}

At 18.27 on 12 December 2015 Laurent Fabius brought down his gavel to mark the adoption of the Paris Agreement by nearly 200 countries. Even the most optimistic commentators agree that the scale and speed of the action needed to realise the ambitions of the Agreement is daunting. The history of action on climate change gives us no grounds for optimism. But perhaps we still have grounds for hope (McKinnon 2014).

Many things could snuff out this fragile hope. In this paper I shall address conduct that explicitly aims to do so: climate change denial (from here on in, 'climate denial'). By 'climate denial' I mean the deliberate and deceptive misrepresentation of the scientific realities of climate change, such as the fact that climate change is happening, its anthropogenic causes, and its damaging impacts (Dunlap 2013). What I do not mean by 'climate denial' are minority or outlier positions on aspects of climate science that lie within the range of normal and healthy disciplinary disagreement. There is an established international network of well funded organisations devoted to organised climate denial, and their activity is on the increase (Boussalis and Coan 2016). The epicentre of this activity is in America, where climate denial has had a significant impact on public opinion (Leiserowitz et al 2014), and has impeded legislation to tackle climate change (Farrell 2016; Oreskes and Conway 2012).

\footnotetext{
${ }^{1}$ I would like to thank Ed Hawkins and Patrick Tomlin for their helpful comments on an earlier draft.
} 
My question is: should we tolerate climate denial? The 'we' in this question refers to broadly liberal people and legislators in democratic societies, for whom principles of toleration and the virtue of tolerance are of fundamental importance in social and political life. Toleration is a matter of principled selfrestraint with respect to conduct that would alter, suppress, or prevent the characteristics or conduct of people opposed by the tolerator (McKinnon 2006; McKinnon and Castiglione 2003). The tolerant agent refrains from interfering with those she dislikes or of whom she disapproves even when she believes that her dislike or disapproval is well-grounded. The agents of toleration can be individual people - when toleration is likely to manifest as a virtue, or as a civic disposition - or institutions, when fundamental political principles, the constitution, and laws and their implementation, are framed to respect the limits of toleration (McKinnon 2013). Toleration is difficult to justify and hard to practice at both the personal and institutional level, particularly for liberals (Scanlon 2003a). Liberalism is committed to freedom of association, conscience, worship, movement and expression as a matter of fundamental principle (Rawls 1971). This delivers a distinctive liberal, permissive vision of the limits of toleration with respect to acts of expression. Given that climate denial is achieved through acts of expression there is a heavy burden of proof attached to any liberal proposal to be intolerant of climate denial. ${ }^{2}$

My aim in this short paper is to identify the proper site for this debate. What are the questions to be answered in deciding whether climate denial lies beyond the limits of liberal toleration? Although I do not answer these questions,

\footnotetext{
${ }^{2}$ I ignore here the many ways in which this case could be made on illiberal grounds.
} 
by correctly identifying them I hope to show that the burden of proof is perhaps not as heavy as we initially might have thought.

\section{Climate denial and climate science}

Climate science is complicated, and its uncertainties have roots that are difficult for lay people to understand. Climate experts have not done a wonderful job of communicating this to the rest of us (Aven and Renn 2015), and climate deniers have taken advantage of this to assert spuriously that scientists disagree about the core facts of climate change. In fact, $97 \%$ of peer reviewed papers published between 1991 and 2011 taking a position on climate change assert that it is happening and that it is anthropogenic (Skeptical Science 2016a).

However, the fact that deniers misrepresent climate science is not sufficient to justify intolerance of climate denial in the form of legal prohibition, and the fact that deniers' misrepresentations are deliberate makes no difference to this conclusion. In his celebrated discussion of freedom of expression, J.S. Mill distinguishes three types of case in which minority opinions clash with those of the majority, in order to assess the limits of liberal toleration in each case (Mill 1989). (1) When a contested opinion is false and could be corrected by contestation; (2) when a contested opinion is true, but contestation could benefit the opinion-holder and wider humanity; (3) when the opinion contested and that contesting it share a portion of the truth, in which case contestation benefits everyone. Because climate denial is false it can only fit into the second of these categories. Specifically (and to use Mill's example), climate denial prima facie could qualify as contestation of the theories of climate science in the same way that the theory of phlogiston counts as contestation of the now dominant theory of oxygen. Mill argues that in such cases contestation is what enables one theory 
or approach to triumph over another. It ensures that scientists fully understand the grounds of their scientific beliefs, and have justified confidence in the truth of their theory or the veracity of their findings. For climate denial to fit Mill's second model it has to be the case that either it benefits scientists, or it benefits wider humanity (or both). Are any of these things true?

Contestation in science is what opens up new fields of scientific enquiry: contestation can falsify a conjecture, shift a paradigm, or make a research programme degenerate. Contestation is also a continuous process whereby refutations of conjectures are attempted, scientific paradigms are refined, or research programmes are developed. Present climate denial does not fit these models of contestation: it is anti-scientific. Climate deniers are not scientists with beliefs about climate change that differ from scientists in the mainstream: climate deniers are not scientists at all. Many of them are not trained in climate (or any) science, their methods are unscientific (cherry picking data or making fundamental errors such as confusing weather events with long term climate trends), and they do not submit their writings to professional peer review. The anti scientific contestation of climate science offered by deniers is of no benefit to climate scientists themselves, and it is legitimate for them to be denied employment in and access to universities and research institutions, and to be ineligible for resources (such as funding for research) which society makes available to support real scientists in their work.

The conclusion that climate denial is of no benefit to scientists and ought not to be tolerated in the Academy is not very surprising. ${ }^{3}$ It certainly has no

3 The case here is similar to that for excluding Holocaust deniers from the Academy. See McKinnon 2007. 
implications for whether climate denial ought to be legally prohibited. Although climate denial does not benefit climate scientists, perhaps it benefits the rest of us by improving our understanding of climate science. Perhaps climate deniers are gad flies to climate scientists, forcing them to do better in communicating the realities of climate change and the uncertainties of climate science to lay people. And when the public better understand climate change it becomes more likely that effective action will be taken to tackle it (Vainio and Paloniemi 2011). It is true that scientists should do more to improve public understanding of climate science (Anderson and Bows 2012; Brysse, Oreskes, O’Reilly and Oppenheimer 2013). But climate denial in the actual world is very far from the gad fly model, which makes a Millean appeal to its social utility unconvincing as a foundation for tolerating it.

A different, non-consequentialist line of argument for tolerating climate denial is that people have significant, autonomy-related interests in being able to say whatever they want in public spaces, even when what they say is nonsense and has no social utility at all (Scanlon 2003b). Part of what defines a society as democratic is that its members are free to voice idiotic opinions in the pub that would get them laughed out of an academic lecture theatre, all else being equal. One way in which all else might not be equal is when what is expressed stirs up hatred, causes profound offence, or defames a particular group of people (Feinberg 1988). However, climate denial is not like this: it is not part of a vehicle to hurt and oppress people with particular group-based identities. It is true that some prominent climate scientists have suffered smear campaigns, death threats, and intimidation at the hands of climate deniers (Mann 2013), but these expressive acts are distinct from the denial of climate science I am 
addressing here and are straightforwardly outside the limits of toleration on any account of it (as reflected in statutes in the UK such as the Protection from Harassment Act 1997 and the Offences Against the Person Act 1861).

Nevertheless, there other ways in which all else is not equal with respect to climate denial, and which would be sufficient in at least some spheres to override the powerful liberal commitment to freedom of expression as a fundament of a democratic society. I shall argue that the following features of climate denial could put it beyond the scope of an autonomy based defence of freedom of expression: climate denial is propaganda that disguises the harmful externalities of the fossil fuel industry, and these externalities are a significant cause of present climate change which is endangering human security on a global and intergenerational scale. Propagandising climate denial is generated and spread by conservative think tanks funded by the fossil fuel industry.

\section{Climate Denial and Conservative Think Tanks}

The climate denial that has perverted legislation to tackle climate change (especially in the U.S.), and that has skewed public opinion so as to emasculate the demos of the world's biggest per capita polluting nation in the face of the climate crisis, is not the sum of individual acts of free expression as people chew the fat in the pub on a Friday night. The climate denial with respect to which all else is not equal in the application of autonomy-based liberal arguments for freedom of expression is a set of well organised, well funded, strategic, deceptive, ideological practices undertaken by a range of Conservative Think Tanks in the U.S. which are heavily funded by the fossil fuel industry. I shall call this 'industrial' climate denial, which reflects its scale, systematicity and its sources of funding. Using misrepresentation, fallacious reasoning and cherry picking of 
data, the climate denial strategies of these organisations are as follows (Washington and Cook 2011).

1. Claims that climate scientists are in a global conspiracy. For example, in 2009 servers at the University of East Anglia were hacked and emails from climate scientists working in the Climate Research Unit were stolen. The emails were mined by deniers to support their claims that climate scientists are part of a conspiracy to deceive the public about the reality and severity of climate change (they called this 'Climategate') (Leiserowitz et al 2012). Three independent enquiries completely exonerated the scientists involved (Skeptical Science 2016b).

2. Appeals to fake experts. For example, the Heartland Institute publishes 'Not The IPCC' (NIPCC) reports which are mocked up to look very similar to the IPCC Reports but which deny the science of climate change. The Heartland Institute is a right wing think tank heavily funded by the fossil fuel industry. ${ }^{4}$ In the 1990 s it worked closely with the tobacco company Philip Morris to lobby against government public health reforms related to second-hand cigarette smoke, and for over a decade it has been one of the most active climate denial organisations in the US (Greenpeace USA 2013; Oreskes and Conway 2012). The NIPCC reports only review papers published by climate deniers, whereas the IPCC reports review the

\footnotetext{
${ }^{4}$ The Cato Institute is very similar. See http://www.desmogblog.com/2012/10/23/media-watch-will-cato-dupe-mediacounterfeit-govt-copycat, accessed 3/12/13.
} 
totality of the literature. As indicated earlier, there is no doubt about the facts: of the 13950 peer reviewed climate articles published 1991-2012, only 24 reject global warming. ${ }^{5}$ Furthermore, $92 \%$ of the Englishlanguage books promoting denial are either written by employees of climate denial organisations, or are published by those organisations, or both (Jacques, Dunlap and Freeman 2008; Dunlap and Jacques 2013; Brulle 2014).

3. Setting impossible expectations. Using this tactic, deniers highlight the uncertainties in climate models, and disagreements between climate scientists, to argue that the science is not established and thus that the grounds for action on climate change are insecure. This argument is fallacious: the bar for action on a proposition is rarely $100 \%$ certainty, in both political and personal life. Most of the time, what we want to know before acting is (a) that the proper scientific methods have been used to arrive at the proposition, and (b) that most scientists in the field agree about it (Anderson 2011). With respect to (b), by engaging in massive periodic literature reviews, the IPCC Reports identify what is agreed upon by most climate scientists as the field develops. With respect to (a), climate models are standardly assessed using 'hindcasting', which tests how well the models can reproduce past global temperature changes: only those hindcasts that include anthropogenic forcings accurately track observed changes since 1850 (Skeptical Science 2016c).

\footnotetext{
${ }^{5}$ http://desmogblog.com/2012/11/15/why-climate-deniers-have-no-
} credibility-science-one-pie-chart, last accessed 2/12/13. 
4. Outright deception. A prime example is Exxon's 'big lie'. ExxonMobil is the world's largest oil and gas company. An investigation in 2015 revealed that top executives in Exxon knew about the warming effects of $\mathrm{CO} 2$ and the danger to humanity posed by climate change in the late 1970s, funding their own in house research to confirm this knowledge, and then developing and executing their plans for Arctic fossil fuel exploration to take account of the effects of climate change on the region (Inside Climate News 2016). Throughout this period Exxon spent upwards of $\$ 20 \mathrm{~m}$ to fund climate denial and defeat climate legislation in the US (Greenpeace International 2016).

It would be easy to dismiss each node in the network of industrial climate denial as an isolated event, undertaken by cranks, and amplified by the internet. This is false of the activities just described which are part of a well orchestrated, well funded strategy to undermine climate science so as to enable fossil fuel industries to prosper. Recent research has confirmed the connections between corporate-funded industrial climate denial and the ideological polarisation that is effective in delaying progress on environmental policy (Farrell 2016). Arguably, industrial climate denial is a symptom of serious problems in the U.S. political system that have allowed corporations to distort democratic politics (Mayer 2016; Dworkin 2013). But we can address the question of whether we ought to tolerate industrial climate denial without a full blown analysis of the ideal of democracy and the place of corporate money in this ideal. Instead, we should start by considering industrial climate denial as propaganda. 


\section{Industrial climate denial as propaganda for the fossil fuel industry}

The type of propaganda of which industrial climate denial is a token is what Jason Stanley calls 'Undermining Demagoguery'.

A contribution to public discourse that is presented as an embodiment of a worthy political, economic, or rational ideal, but is in the service of a goal that tends to undermine that very ideal (Stanley 2015: 69).

Undermining demagoguery invokes worthy ideals which are likely to be eroded by the goals that the demagoguery really serves. Industrial climate deniers claim allegiance to the following ideals: the rational ideal of good science (in revealing uncertainties in climate science); the political ideal of transparency (in uncovering a conspiracy); the economic ideal of prosperity for all (in sparing Americans the unnecessary economic burdens of mitigation and adaptation policies). In fact, industrial climate deniers: are not doing science, and do not improve the quality of the work of climate scientists; keep their deep connections with the fossil fuel industry opaque; and recommend policies that protect and promote the economic interests of a fossil fuel industry elite at the expense of the interests of humanity as a whole, present and future. The goal of industrial climate denial is to stymie action on climate change that would decrease the profits of the corporations with economic interests in the continuation of a carbon-based global economy (Mayer 2016). Industrial climate deniers are undermining demagogues because they present conduct in pursuit of that goal as serving other worthy ideals. 
Undermining demagoguery can be present when those doing it are aware of the ways in which their propagandising undermines the ideals they claim to uphold, in which case the demagogues are engaged in deception. But it can also be present when demagogues and their audiences are blind to that fact that undermining demagoguery binds them together in communication. In these cases, Stanley argues, both parties are in the grip of a flawed ideology that masks the inconsistencies of the propaganda (Stanley 2015, chapters 5 and 6). Thus, the intentions, beliefs and motives of a speaker are irrelevant to determining whether they are engaged in undermining demagoguery. If those engaged in industrial climate denial sincerely believe the falsehoods they propagate, are motivated by the desire to correct what they perceive to be bad science on climate, and intend to make the world a better place by so doing, they may nevertheless be engaged in undermining demagoguery.

In fact, there is abundant evidence that industrial climate deniers are fully aware that their propaganda is false, and so are engaged in straightforward deception of the public and policymakers at whom their communications are aimed. It is well documented that present industrial climate denial has its roots in the PR used by the tobacco industry for decades to deny the harmful effects of smoking cigarettes, and of second-hand smoke. ${ }^{6}$ The propagandists for Philip Morris asserted 'Doubt is our product'; the propagandists for ExxonMobil

\footnotetext{
6 There are a number of 'career deniers' whose names reappear repeatedly in campaigns of deception about tobacco, ozone depletion, and climate change: for example, Fred Singer, Fred Seitz, Bill Nierenberg, and Robert Jastrow (Oreskes and Conway, 2012).
} 
claimed that, 'Victory will be achieved when the average person is uncertain about climate science' (Hall 2015).

The tobacco industry's PR campaign lies beyond the limits of toleration on any account of it: every person has the right to have accurate information about the potential harms to health of products they consume, insofar as that information can be provided by producers. The tobacco PR campaign directly violated these rights. For these reasons the campaign should have been legally prohibited through regulation of the vehicles through which it was pursued (Hilts 1996). However, the case of industrial climate denial is not so straightforward. Industrial climate denial is not mis-selling of a product. Acquiring false beliefs about climate change as a result of exposure to denial is unlikely to cause direct harm to the health of anyone who has been exposed to it. Indeed, perhaps the opposite is true: perhaps better mental health can be secured by a doxastic turning away from the frightening realities of climate change. ${ }^{7}$ The fact that industrial climate denial is undermining demagoguery is the key to understanding whether it ought to be tolerated, but not in virtue of how it damages the health of individual people. Instead, the damage that matters is to human security on a global and intergenerational scale.

\section{Climate denial as a threat to human security}

Earlier on I characterised liberalism in terms of its distinctive commitment to freedom of expression as a fundament of any just society. A further fundamental commitment (with a longer pedigree) is to the security of

\footnotetext{
${ }^{7}$ Perhaps this turning away is an unavoidable coping mechanism for creatures with our evolutionary history and cultures (Norgaard 2011)..
} 
the individual. Going back to at least John Locke, liberals have argued that one of the basic functions of the state is to secure for individuals political and social conditions in which they can live, indeed flourish, with dignity. There has been much internecine debate about what these conditions are, what sorts of political structures best secure them, and whether the nation state is the ideal site for these structures. For many historical liberal thinkers, the biggest threat to individual security was government, via intrusions on liberty, property rights, or anti democratic grabs on political power. Recently, the security necessary for human flourishing and dignity has been well captured in the idea of human security, which directs attention to the multifarious ways in which lives can be stunted and diminished. The core of this approach is the thought that hunger, disease, poverty, and restricted access to food and water can be as damaging to dignity and flourishing as threats of violence and political repression (UNDP 1994; Commission on Human Security 2003).

Climate change damages human security on a global and intergenerational scale. Even if all countries achieve the GHG reductions laid out in the INDCs that fed into the Paris Agreement (Climate Action Tracker 2016), average temperatures are likely to rise by between 2.7C and 3.5C by 2100 . Temperature rises in this range will catastrophically damage food production and security, increase disease, cause conflict over scarce resources, and displace millions of people and deprive them of their livelihoods and cultures (IPCC 2014). Even if INDCs are fully achieved, the effects of cumulative emissions to date are likely to last 10,000 years (Clark et al 2016).

Taking human security seriously enables us to settle on the correct frame for the question of whether industrial climate denial ought to be tolerated. To 
start, consider Justice Holmes famous statement that ' $[t]$ he most stringent protection of free speech would not protect a man falsely shouting fire in a theatre and causing a panic'. ${ }^{8}$ In a crowded theatre, the interests people have in not being put at risk of injury and death in a stampede to escape as a result of a false alarm outweighs any interest the speaker has in shouting 'Fire!' when there is no fire, and so the speaker ought to be silenced. Note here that this argument makes no reference to the sincerity of the speaker's false belief: if the belief is false, in this context, she should not be permitted to shout it out, regardless of whether she sincerely believes that there is a fire.

Is industrial climate denial like this? There are clear ways in which it is not. Mostly, deniers are not personally as close in space or time to those they address as the speaker in the theatre. And their means of communication is mostly non-vocal. However, these dissimilarities make no moral difference. The spatial and temporal propinquity of speakers to people whose interests could be set back by their speech is not necessary for the speech to endanger those interests. The transmission of a fake alarm call of 'Fire!' recorded weeks earlier and beamed in to a theatre from the other side of the world ought to be prohibited for the same reasons that apply to the speech that happens in the theatre. Instead, what justifies interference with the speech in the theatre is that in that context there is very limited, or no, opportunity for intervening speech to correct the false impression which could cause a stampede, and the conventions around shouting an alarm mean that people are likely to trust its veracity. Once

\footnotetext{
8 Schenck v. United States, 249 U.S. 47 (1919).
} 
'Fire!' is shouted, people panic, and countervailing shouts of 'False alarm!' are unlikely to be heeded.

Is the context for industrial climate denial like this? One way in which it differs is that whereas the speaker in the theatre is trying to convince people that a danger exists when there is none, deniers are trying to convince people that a really existing and serious danger does not exist, or is not very serious. Another difference is that there are exits from the theatre that lead to safety, whereas there is no exit from planet Earth and the dangerous climate change that will ravage it for millennia to come if we do not take drastic action immediately. For these reasons, the speech of industrial climate deniers is far worse than the person in the original 'Fire!' example. Taking account of these differences, here is how the theatre example ought to be recast to capture what is morally salient to the question of whether industrial climate denial ought to be tolerated.

A fire has started in the theatre, from which there are no exits. Unchecked, the fire will kill and injure many in the theatre, especially those in the cheapest seats. Many people can smell the smoke, but many others have not yet noticed and are still enjoying the show. Some speakers are trying to warn everyone so that the fire can be contained before it quickly spreads out of control; their warnings are measured and calm, and reflect the consensus among them on the causes, severity and likely impacts of the growing fire. Another group - sitting mainly in the most expensive seats - are trying to shout louder that there is no fire, or that it is not serious, or that there is plenty of time left to put it out. This group uses far more emotive and alarmist language, and shouts a lot about how the other group are not to be trusted. Many of the people in the theatre are either confused by these conflicting messages, or are convinced by the fire-deniers; 
there are enough people in this combined set to significantly slow down the efforts of those listening to the accurate warnings who are trying to put out the fire. In this scenario those shouting 'No fire!' ought to be silenced because there is a fire that requires urgent and immediate action to prevent it from spreading and becoming uncontrollable, but the fire is not being tackled properly because many of the people in the theatre do not know who to trust.

Focusing on this kind of crowded theatre scenario shows the proper site for debates about whether industrial climate denial ought to be tolerated. Ideally, people in the theatre would be properly equipped to judge with accuracy that the group issuing the calm and measured warnings is to be trusted. Ideally, this group would improve the ways in which it communicates its well grounded warnings so as to better enable the people in the theatre to see the danger they are in. And then, ideally, people would ignore the 'No Fire!' group, and take action to put out the fire. But if the fire could spread out of control before it is feasible for the transformations just described to take place, then the 'No Fire!' group ought to be silenced because of how their speech endangers everyone in the theatre.

In conclusion, in order to decide whether industrial climate denial ought to be tolerated in the context of real world climate change, here are the questions we ought to ask, followed by the answers that would support placing industrial climate denial beyond the limits of liberal toleration. First, is industrial climate denial throwing sand in the wheels of mitigation efforts? (Yes). Second, if lay people were better able to judge accurately the veracity of climate science (and the falsity of industrial climate denial) would more progress on mitigation be likely? (Yes). Third, if climate scientists became better at communicating the 
scientific realities of climate change, would mitigation increase? (Yes). Finally, is there time to effect these changes within the present window for aggressive mitigation, beyond which there is a real risk that humanity locks in to catastrophic global climate change? (No). ${ }^{9}$

I will not argue for any of the answers in parentheses here, although I think they are all correct. Those who take a different view on the fourth question in particular should consider the stakes in the light of the following facts about lay people and scientists in the world as it is. Since at least the 1980s many learned societies have been strenuously advocating action to evolve the public understanding of science, but it is not clear that much progress has been made (Bauer 2009). And with respect to the science community, modern science has deep methodological commitments which strongly incline it to caution and conservatism in its assertions (Brysse et al 2013). Neither of these facts is unalterable. The question is: given the possibility that climate change could run out of our control if we do not aggressively mitigate now, should we place high bets on successfully altering these facts at speed, or on taking emergency measures to prohibit industrial climate denial?

\footnotetext{
${ }^{9}$ See The Trillionth Ton for different estimates of when this window will close. http://www.trillionthtonne.org/. Last accessed 22 February 2016.
} 


\section{$\underline{\text { References }}$}

Anderson, Elizabeth. 2011. 'Democracy, Public Policy, and Lay Assessments of Scientific Testimony'. Episteme 8(2), 144-64.

Anderson, Kevin and Bows, Alice. 2012. 'A New Paradigm for Climate Change', Nature Climate Change 2, 639-40.

Aven, Terje, and Renn, Ortwin. 2015. 'An Evaluation of the Treatment of Risk and Uncertainties in the IPCC Reports on Climate Change'. Risk Analysis 35(4) 701-712.

Bauer, Martin. 2009. 'The Evolution of Public Understanding of Science Discourse and Comparative Evidence'. Science, Technology and Society 14(2), 221-40.

Boussalis, Constantine and Coan, Travis G. 2016. 'Text mining the signals of climate change doubt'. Global Environmental Change 36, 89-100.

Brulle, Robert J. 2014. 'Institutionalizing delay: Foundation Funding and the Creation of U.S. Climate Change Counter-Movement Organisations'. Climatic Change 122, 681-94.

Brysse, Keynyn, Oreskes, Naomi, O’Reilly Jessica, and Oppenheimer, Michael. 2013. 'Climate Change Prediction: Erring on the Side of Least Drama?'. Global Environmental Change 23, 327-37.

Clark, Peter, Shakun, Jeremy, Marcott, Shaun, Mix, Alan, Eby, Michael, Kulp, Scott, Levermann, Anders, Milne, Glenn, Pfister, Patrik, Santer, Benjamin, Schrag, Daniel, Solomon, Susan, Stocker, Thomas, Strauss, Benjamin, Weaver, Andrew, Winkelmann, Ricarda, Archer, David, Bard, Edouard, Goldner, Aaron, Lambeck, Kurt, Pierrehumbert, Raymond, Plattner, Gian-Kasper. 
2016. 'Consequences of twenty-first-century policy for multi-millennial climate and sea-level change', Nature Climate Change 08 February 2016.

Climate Action Tracker. 2016. 'Tracking INDCs'. Last accessed 16 February 2016. http://climateactiontracker.org/indcs.html

Commission on Human Security. 2003. Human Security Now.

Dunlap, Riley E. 2013. 'Climate Change Skepticism and Denial: An Introduction'. American Behavioral Scientist 57(6), 691-8.

Dunlap Riley E., and Jacques, Peter J. 2013. 'Climate Change Denial Books and Conservative Think Tanks: Exploring the Connection'. American Behavioral Scientist 57(6), 699-731.

Dworkin, Ronald. 2013. 'The Decision That Threatens Democracy'. New York Review of Books, May 13.

Feinberg, Joel. 1988. Offense to Others: The Moral Limits of the Criminal Law, Part 2. Oxford: Oxford University Press.

Greenpeace International. 2016. 'Exxon Secrets'. Last accessed 15 February 2016. http://www.exxonsecrets.org/maps.php

Greenpeace USA. 2013. 'Dealing in Doubt: The Climate Denial Machine vs Climate Science'. Last accessed 15 February 2016.

http://www.greenpeace.org/usa/en/campaigns/global-warming-andenergy/polluterwatch/Dealing-in-Doubt---the-Climate-Denial-Machine-vsClimate-Science/

Hall, Shannon. 2015. 'Exxon Knew About Climate Change Almost 40 Years Ago'. Scientific American, October 26 2015. Last accessed 16 February 2016. http://www.scientificamerican.com/article/exxon-knew-about-climatechange-almost-40-years-ago/ 
Hilts, Philip J. 1996. Smokescreen: The Truth Behind the Tobacco Industry Cover Up. Boston: Addison-Wesley.

Inside Climate News. 2016. 'Exxon: The Road Not Taken'. Last accessed 15

February 2016. http://insideclimatenews.org/content/Exxon-The-RoadNot-Taken

IPCC. 2014. Climate Change 2014: Impacts, Adaptation, and Vulnerability. Part B: Regional Aspects. Contribution of Working Group II to the Fifth Assessment Report of the Intergovernmental Panel on Climate Change [Barros, V.R., C.B. Field, D.J. Dokken, M.D. Mastrandrea, K.J. Mach, T.E. Bilir, M. Chatterjee, K.L. Ebi, Y.O. Estrada, R.C. Genova, B. Girma, E.S. Kissel, A.N. Levy, S. MacCracken, P.R. Mastrandrea, and L.L. White (eds.)]. Cambridge University Press, Cambridge, United Kingdom and New York, NY, USA. Jacques, Peter, Dunlap, Riley and Freeman, Mark. 'The Organisation of Denial: Conservative Think Tanks and Environmental Skepticism'. Environmental Politics 17(3), 349-85.

Farrell, Justin. 2016. 'Corporate Funding and Ideological Polarisation About

Climate Change'. Proceedings of the National Academy of Sciences of the United States of America 113(1), 92-7.

Leiserowitz, Anthony, Maibach, Edward, Roser-Renouf, Connie, Feinburg, Geoff, Rosenthal, Seth. Climate Change in the American Mind: April 2014. 2014. Yale University and George Mason University. Yale Project on Climate Change Communication, New Haven, CT. Leiserowitz, Anthony, Maibach, Edward, Roser-Renouf, Connie, Smith, Nicholas and Dawson, Erica. 2012. 'Climategate, Public Opinion, and the Loss of Trust'. American Behavioral Scientist 57(6), 818-37. 
Mann, Michael. 2013. The Hockey Stick and the Climate Wars. New York:

Columbia University Press.

Mayer, Jane. 2016. Dark Money: The Hidden History of the Billionaires Behind the Rise of the Radical Right. Doubleday Books.

McKinnon, Catriona. 2014. 'Climate Change: Against Despair'. Ethics and the Environment 19(1), 31-48.

McKinnon, Catriona. 2013. 'Vertical Toleration as Liberal Ideal', Social Theory and Practice 39(1), 1-18.

McKinnon, Catriona. 2007. 'Should We Tolerate Holocaust Denial?'. Res Publica 13(1), 9-28.

McKinnon, Catriona. 2006. Toleration: A Critical Introduction. London: Routledge.

McKinnon, Catriona, and Castiglione, Dario, eds. 2003. Toleration, Neutrality and Democracy. Dordrecht: Kluwer.

Mill, John Stuart. 1989. On Liberty. Cambridge: Cambridge University Press.

Norgaard, Kari Marie. 2011. Living in Denial: Climate Change, Emotions, and Everyday Life. Cambridge, Mass.: MIT Press.

Oreskes, Naomi and Conway, Erik M. 2012. Merchants of Doubt: How a Handful of Scientists Obscured the Truth on Issues From Tobacco Smoke to Global Warming. Bloomsbury.

Rawls, John. 1971. A Theory of Justice. Oxford: Oxford University Press.

Scanlon, T.M. 2003a. 'The Difficulty of Tolerance'. In The Difficulty of Tolerance by T.M. Scanlon, 187-201. Cambridge: Cambridge University Press. 
Scanlon, T.M. 2003b. 'A Theory of Freedom of Expression'. In The Difficulty of Tolerance by T.M. Scanlon, 187-201. Cambridge: Cambridge University Press.

Skeptical Science, 2016a. 'The 97\% Consensus on Global Warming'. Last accessed 15 February 2016. http://www.skepticalscience.com/global-warming$\underline{\text { scientific-consensus-advanced.htm }}$

Skeptical Science 2016b. 'What do the Climategate hacked CRU emails tell us?'. Last accessed 15 February 2016.

http://www.skepticalscience.com/Climategate-CRU-emails-hackedadvanced.htm.

Skeptical Science 2016c. 'How reliable are climate models?'. Last accessed 15 February 2016. http://www.skepticalscience.com/climate-modelsintermediate.htm

Stanley, Jason. 2015. How Propaganda Works. Princeton: Princeton University Press.

United Nations Development Programme. 1994. Human Development Report 1994. New York: Oxford University Press.

Vainio, Annukka and Paloniemi, Riikka. 2011. 'Does Belief Matter in Climate Change Action?'. Public Understanding of Science 22(4), 382-95.

Washington, Haydn and Cook, John. 2011. Climate Change Denial: Heads in the Sand. London: Earthscan. 